\title{
REGIONAL POLICY FINANCIAL INSTRUMENTS IN THE SZCZECIN METROPOLITAN AREA
}

\section{ELŻBIETA OCIEPA-KICIŃSKA ${ }^{1}$}

\begin{abstract}
The progressing "metropolisation" of the economy is connected with the intensive development of some cities considered to be metropolises or potential metropolises. One of the prerequisites needed to achieve a good rate of development is providing support to enterprises in the form of financial instruments constructed in such a way that their implementation will contribute to stimulation of the economy within a given area. The aim of this paper is to review and systematise the concept of regional policy financial instruments operating in the Szczecin Metropolitan Area (SMA). In the academic literature on the subject, the concept is rarely addressed, and it accounts for only some areas of financing or focuses on selected sources of finance. On that basis, an analysis was made along with a selection of regional policy financial instruments that are in place in the SMA. The specific entities functioning within the business environment institutions in the SMA are discussed along with the kinds of financial instruments offered by them.The analysis resulted in identifying 11 institutions whose range of operations include offering regional policy financial instruments to entrepreneurs.
\end{abstract}




\section{INTRODUCTION}

The world economy is metropolised and in the knowledge-based global economy, metropolises are decisive for the developmental potential of a given country. On the one hand, metropolises are considered to be the highest form of spatial organisation in the network society, on the other hand, due to the multitude of definitions and criteria applied in classifying any specific areas as metropolitan, it is difficult to indicate exactly how many metropolitan areas are now found in Poland. However, it is undeniable that in terms of the national and international definitions quoted in this article, the city of Szczecin together with the adjacent areas qualify as a developing metropolitan area.

Development relies first and foremost on supporting entrepreneurial growth within a given area. On the regional level, it is possible to distinguish the following kinds of support: hard support in the form of infrastructural instruments, soft support based on training and advisory measures, and financial support. This paper focuses on regional policy financial instruments, understood in a broad sense, which are dedicated to entities running their business activity in the Szczecin Metropolitan Area. The concept is rarely addressed and it accounts for only some areas of financing or focuses on selected sources of finance. The definition of metropolitan areas and the characteristics of the Szczecin Metropolitan Area are discussed, and then specific entities are identified and discussed regarding their functioning within the business environment institutions in the SMA with the kinds of financial instruments offered by them.

The paper also attempts at reviewing the definitions of the concept of regional policy financial instruments, whereas its empirical part analyses some specific financial entities that operate in the SMA, and identifies particular financial instruments offered by them.

\section{METROPOLITAN AREAS IN POLAND}

The concept of a metropolis is one of the most characteristic, though indistinct concepts in regional and spacial sciences (Śleszyński \& Komornicki, 2008, p. 2). In many regions in the world, especially where a high urbanisation rate has been achieved, the economy has progressed to the post-industrial phase and to an information society, and consequently the city development has attained a qualitative nature. In a relatively small group of cities, there are functions related to society management on a scale exceeding the region, or even the country, and to development of a knowledgebased information economy. It is considered to be the most important feature of "metropolisation" which in this context should be understood as (Lendzion et al., 2004, pp. 4-5):

1) emergence, on the basis of some big cities, of metropolises being a network of centres exerting a dominating influence on major processes of the contemporary civilisation development, fulfilling the flow management functions on a global or (sub)continental scale, which are interconnected with a network of contacts and flows, partially independent from the regional environment,

2) significant diversification of the regional space within the impact range of the centres, including emergence, within the close range (of up to ca. $30-40$ $\mathrm{km}$ ), of metropolitan areas composed of towns and settlements, and a very selective, often dominantly negative impact on their distant regional hinterland.

OECD defines metropolitan areas as functional urban areas covering urban centres of high population density (at least 1,500 inhabitants per square kilometre) and adjacent municipalities that are provided with a good transport infrastructure enabling commutation of employees from the surrounding areas to the urban centres). The minimum population threshold for functional urban areas is $50,000^{2}$. (OECD, 2018, p. 13). Polish law still lacks legal regulations regarding metropolises. As per the Act of 9 October 2015 on metropolitan associations, repealed in 2017, a metropolitan area is defined as a spatially coherent zone of impact of a city which is the seat of a voivodeship governor or a voivodeship council, characterised by existence of strong functional connections and advanced urbanisation processes, inhabited by at least 500,000 residents. Kaczmarek (2019) defines metropolitan areas as complex settlement, administrative and economic structures characterised by the following features:

1) big-city settlement network consisting of a big central city (or several central cities), a suburban

\footnotetext{
2 The purpose of this approach to functional urban areas is developing a methodology which may be applied throughout the OECD, thus increasing the comparability across the countries, as opposed to the definitions and methodologies developed in any individual countries.
} 
zone and a functional zone connected with the urban agglomeration,

2) administrative fragmentation, i.e. complexity of territorial management structure, comprising cities and municipalities, as well as subregional territorial units (poviats, districts, counties, departments, provinces),

3) network of infrastructural, transport as well as spatial and functional interconnections, characterised by intensive flows of goods, people, capital and information.

In the National Spatial Development Concept 2030 (NSDC 2030) adopted by the Polish government in 2011, which is the top level national strategic document regarding the country's spatial management, metropolitan centres were determined according to the following criteria ${ }^{3}$ :

1) population of a metropolitan centre: above 300,000 residents,

2) employment in the market service sector (financial agency services and services rendered to companies and in relation to real properties): above 40,000,

3) number of tertiary students studying in the given city in the academic year 2007/2008: above 60,000,

4) cooperation of R\&D institutions in the EU 5th and 6th Framework Programme,

5) an airport serving passenger traffic,

6) four- and five-star hotels,

7) international exhibitions in exhibition facilities in 2006-2008.

At the time of adopting the NSDC, the criteria were met by the following cities: Warsaw, Upper Silesia Agglomeration (main centre: Katowice), Kraków, Łódź, Trójmiasto (Tricity), Poznań, Wrocław, duopolis of Bydgoszcz \& Toruń, and Szczecin. Lublin met the criteria required to qualify as a metropolis with the exception of having a passenger airport. Nevertheless, due to its importance for development, e.g. in the area of academic potential and concentration of business activity, and due to its contacts with the countries located east of Poland, Lublin was listed as a metropolitan centre.

Under the ESPON project ${ }^{4}$ no. 1.4.3. Study on Urban

\footnotetext{
${ }^{3}$ As per 2009 data.

${ }^{4}$ ESPON(European Observation Network for Territorial Development and Cohesion) - a research program regarding Europe's spatial development.
}

Function, Functional Urban Areas (FUA) were identified, within the framework of which Metropolitan European Growth Areas (MEGA) were determined. Among MEGAs, four categories of metropolises were distinguished, and they included 8 centres in Poland. The criteria for a European potential MEGA (rank III) were met only by Warsaw. The other centres were qualified as weak MEGAs (rank IV): Kraków, Katowice (Upper Silesia Conurbation), Tricity (Gdańsk-Gdynia-Sopot), Poznań, Wrocław, Łódź, Szczecin (ESPON, 2007). In turn, the following 12 major Polish cities cooperate within the framework of the Union of Polish Metropolises foundation: Białystok, Bydgoszcz, Gdańsk, Katowice, Kraków, Lublin, Łódź, Poznań, Rzeszów, Szczecin, Warsaw and Wrocław, which describe themselves as major cities of future metropolises and which, despite having merely local competences, step by step develop good practices, also on a supralocal scale, thus building the metropolises from scratch (UMP, 2012).

Development of metropolitan areas is affected by both governmental policies, including first and foremost the regional and industrial policies, as well as by particular actions focused on development of a knowledge-based economy, transport and European networks, sustainable growth and life quality. On the other hand, focusing the growth around metropolitan areas entails the risk of depopulating some regions as a result of intensified migration towards several major cities and local brain drain (emigration of young, active and educated inhabitants). To attain sustainable growth and at the same time to utilise the potential connected with metropolitan area development, the issue of key importance is an ability of efficient co-management of such an area in a mutually advantageous manner by all stakeholders within the area. A regional policy that strives to constrain spatial fragmentation, thus attempting to reconcile metropolitan areas management with the processes currently taking place, should play the key role in this process (Lendzion et al., 2004, p. 36).

The tools to support regional development do not include any special instruments dedicated to metropolitan areas - they make use of instruments dedicated to particular regions where they operate. Naturally, the potential of metropolitan areas combined with the use of regional support instruments make the metropolitan areas the main centres of research, development and implementation of innovations. They host industries with considerable added value, in particular services for enterprises. Metropolitan centres are seats of global 
corporations, and become decision-making centres on an international and global scale. Simultaneously, metropolises are home not only to technological innovations, but also new cultural ideas, lifestyles and values. Thus, metropolitan areas play a significant role in enhancing the European social model (Smętkowski, Jałowiecki \& Gorzelak, 2009, p. 1).

\section{THE SZCZECIN METROPOLITAN AREA}

The Szczecin Metropolitan Area is one of the major elements of the Polish and European settlement system. In the ESPON classification, it is described as a metropolitan area showing a growth trend, in its initial phase, which constitutes a good basis for attaining sustainable growth and increasing competitiveness in the European Union. It consists of the central city - Szczecin, the capital city of the West Pomeranian Voivodeship - and the adjacent areas that are functionally interconnected with it. The following municipalities are considered to be the most strongly connected with Szczecin: Dobra (Szczecińska), Goleniów, Gryfino, Kobylanka, Kołbaskowo, Nowe Warpno, Stepnica, Police, Stare Czarnowo, Stargard, and also the towns of Stargard and Świnoujście (SOM, p.3). SMA is a metropolitan centre with a unique location at the German border, it is also situated within the impact range of major foreign metropolises. The location of the SMA also determines its significance in the development of Euroregion Pomerania as well as the cross- and transborder cooperation in the Baltic Sea Region (SOM, pp. 3-4).

The integrated development of the SMA is predicated on: coherent and attractive space, modern and competitive economy, educated and identity-aware community, as well as availability of high quality public services. (SOM, p. 6). The SMA mission assumes: achieving the development goals by way of in-depth cooperation between the SMA members, their social and economic partners, and civil society representatives, on the regional, national and international platform. (SOM, p. 7).

${ }^{5}$ A particularly strong impact is the one exerted by Berlin (the German capital metropolis) and the transborder Swedish-Danish Øresund / Copenhagen region (the Baltic metropolis).

\section{REGIONALPOLICYFINANCIALINSTRUMENTS IN THE SZCZECIN METROPOLITAN AREA}

Financial instruments are one of the elements of regional development policy implementation (Pietrowski, 2018, p. 66), in accordance with the assumptions of the EU Cohesion Policy for 2014 - 2020, apart from the obvious benefits resulting from the recirculation of funds in the long run, financial instruments help mobilise additional public or private co-investments aimed at filling the market gaps, pursuant to the priorities of the Europe 2020 strategy $^{6}$, providing support for investments in the form of loans, guarantees, capital and other mechanisms subject to a higher risk. Moreover, the instruments offer various incentive elements aimed at achieving better results ${ }^{7}$ (Europejskie fundusze strukturalne i inwestycyjne na lata 2014-2020, 2015). The current framework also contains some clearly defined principles so as to enable more efficient combinations of financial instruments with other forms of assistance, especially grants (Instrumenty finansowe w polityce spójności na lata 2014-2020, 2014). From the perspective of the region, financial instruments constitute one of the tools to support the social and economic development of the region and to transfer the support provided under the Regional Operational Programme (ROP) (Serwis RPO WZ).

Apart from the means offered by EU funds, regional policy financial instruments also include other kinds of financial assistance dedicated to entities operating in the particular region, implemented mainly in the form of appropriately constructed loans, guarantees and suretyships, public aid e.g. in the form of tax relief and preferential treatment with regard to local taxes, preferential rates of municipal charges, subsidising employee training or financial assistance for start-ups (e.g. incubation programmes). Some of the tools are typical for the activities of special economic zones $(\mathrm{SEZ})^{8}$, whose aim

\footnotetext{
${ }^{6}$ Their implementation structures require additional specialist knowledge and know-how, which helps to increase the efficiency and effectiveness of the assigned public resources.

${ }^{7}$ The principles introduced in the $2014-2020$ programming period are aimed at supporting the application of those instruments and inviting use of them as a more effective and sustainable alternative to complement the traditional financing in the form of grants.

${ }^{8}$ SEZ cover non-residential areas of the country, where business activity may be run on preferential terms, and they constitute one of the state's economic policy instruments.
} 
is to stimulate the regional growth via i.a. attracting new investments, increasing exports and creating new jobs. In view of the subject of this article, the next section will address the financial instruments implemented within the West Pomeranian Voivodeship which comprises the SMA.

In the SMA, there are ca. 30 business environment institutions in operation (Ociepa-Kicińska (2019), and they are described as non-profit institutions having a material and technical base, human resources and competences necessary for providing services for the SME sector (Burdecka, 2004, p. 5). Płoszaj (2013) defines them as a heterogeneous group of entities forming formal networks of organizations supporting innovation and technology transfer, according to Matusiak (2011) business support institutions are the key link in modern systems of economic development support covering an organizationally diverse group of non-commercial institutions, active in the area of supporting entrepreneurship and selfemployment, technology transfer and commercialization, and improving the competitiveness of small and mediumsized enterprises (SMEs), based on the need to seek safe and sustainable foundations for development within regions, making extensive use of the involvement of local communities. Some of them focus mainly on training or consulting activities, or knowledge and technology transfers. Based on the analysis of the areas of activity of individual entities, 11 of them were selected. They may be qualified as entities offering regional policy financial instruments to facilitate the SMA development. These include ${ }^{9}$ :

\section{1) Zachodniopomorska Agencja Rozwoju} Regionalnego SA. (West Pomeranian Regional Development Agency) which i.a. fulfils the function of the Regional Financing Institution (RFI) $)^{10}$ which implements

\footnotetext{
${ }^{9}$ Information obtained from websites of the individual entities.

$10 \mathrm{RFI}$ are regional partners of the Polish Agency for Enterprise Development (PARP), which cooperate in implementing programmes addressed to the micro-, small and medium enterprises sector. Their basic function is to enhance competitiveness of microenterprises as well as small and medium enterprises via: providing information on available subsidy programmes and conditions of participation in those programmes, administrative handling of the implemented programmes, cooperation with PARP with regard to factual and financial monitoring of the implemented programmes, preparing factual and financial reports, maintaining the database of the programme participants.
}

financial instruments for micro-, small and medium enterprises, using the repayable funds under the ROP for the West Pomeranian Voivodeship. It also offers: assistance to start-ups, reguarantees offered under the West Pomeranian Development Fund (loans intended for investment financing, creating new jobs, implementing new technical or technological solutions, purchasing the equipment, etc.), development services (increasing employee qualifications), loans granted within the framework of the West Pomeranian Entrepreneurship Support Fund.

2) Goleniowski Park Przemysłowy (Goleniów Industrial Park) offers 405 ha of areas available for investment, fully provided with utilities, including offices for rent. A part of it ( $35 \mathrm{ha}$ ) has the SEZ status, under which public aid is available: up to $35 \%$ of investment outlays and local tax relief for 5 years with regard to the property tax (i.e. tax on buildings and structures).

3) The Regional Park in Gryfino comprises 160 ha of industrial grounds fully provided with utilities and necessary technical infrastructure. A part of the area has the SEZ status which entitles any investors to use regional assistance in the form of the CIT relief on account of incurred investment outlays or creating new jobs. Additionally, the municipality of Gryfino offers regional assistance in the form of property tax relief.

4) Stargardzki Park Przemysłowy (Stargard Industrial Park) comprises more than 150 ha of attractive grounds prepared for new investments. It offers i.a. local tax relief for entrepreneurs implementing new investment projects and providing new jobs.

5) The incubation programme offered by Technopark Pomerania offers a consulting service package totalling PLN 20,000 per year (it includes i.a. meetings with business management consultants, meetings with experts in the area of: PR, marketing, obtaining external financing, law, EU funds, business management, unlimited access to IT expert network) as well as preferential prices for office space rental.

6) Stargardzka Agencja Rozwoju Lokalnego Sp. z o.o., (Stargard Agency for Local Development) offers competent and comprehensive assistance to investors at any stage of the investment process, including loans (as a financial intermediary under the JEREMIE 2 initiative $)^{11}$ and guarantees (of loans, bid bonds and leases).

7) Polska Fundacja Przedsiębiorczości (Polish Entrepreneurs Foundation) operating in the West 
Pomeranian Voivodeship offers financial assistance as well as training and consulting under i.a. the following programmes: Jeremie 2 Initiative, Loan Guarantee Programme, Training \& Consulting Programme, Capital Investments, Innovation and Investment Fund Pomeranus, EU Programmes, Loan for a Start - Microloan Fund KLON, POMERANUS SEED - Seed Capital Fund, Re:start Project (enhancing the efficiency of measures taken to keep restarters on the labour market).

8) Fundusz Pomerania Sp. z o.o. is involved in providing guarantees for loans, leases and bid bonds. It also offers guarantees under the West Pomeranian Development Fund (in the form of de minimis assistance).

9) SzczecińskiFundusz PożyczkowySp.zo.o.(Szczecin Loan Fund) is a financial intermediary operating under the JEREMIE 2 initiative, offering loans to communities and non-governmental organisations, as well as guarantees.

10) Agencja Rozwoju Metropolii Szczecińskiej Sp. z o.o. (SMA Development Agency) grants guarantees to secure credits/loans contracted by micro-, small and medium enterprises registered and/or running their business activity in the city of Szczecin and the municipalities directly neighbouring the municipality of Szczecin.

11) Fundusz Poręczeń Kredytowych w Stargardzie Sp. z o.o. (Loan Guarantee Fund in Stargard) offers guarantees and loans for micro-, small and medium enterprises, it also runs the Regional Loan Fund POMERANUS.

The above-mentioned business environment institutions are characterised by a diversity of offered financial services, both in terms of their form and financing sources. Many a time these entities also provide aid based on infrastructural instruments and/or training and consulting services. In their offers, they clearly define the conditions to be met by any entities to be granted assistance; one of the key criteria is the specific area of running the business activity (e.g. a specific poviat).

\section{Conclusion}

The aim of this paper is to review and systematise the concept of regional policy financial instruments operating in the Szczecin Metropolitan Area. The specific aspect connected with development of metropolitan areas is related to the global processes and the country's areas of development, in the light of which Szczecin is considered a potential metropolis. Regional policy financial instruments tend to take the form of support measures offered under EU programmes. On the other hand, at the local level entrepreneurs are offered particular (also financial) incentives in order to make a given area an attractive place for investing and running a business activity.

The wide range of support instruments offered by the Business Environment Institutions in the Szczecin Metropolitan Area determines the development of entrepreneurship and achievement of success by local entrepreneurs, and in the long run influences the improvement of the quality of life and meeting the needs of residents (e.g. by limiting the unemployment level or by increasing the income of municipalities from local taxes).

The paper applies the definition of regional policy financial instruments covering all the major forms of financial assistance dedicated to the entities functioning in a specified region. Further analysis included the entities operating in the SMA and offering the above defined instruments to entrepreneurs. The analysis resulted in identifying 11 institutions whose range of operations included offering regional policy financial instruments to entrepreneurs, specifically, these include financial products constructed on the basis of preferential treatment, which makes them more accessible and less costly in relation to the market offer. Based on the prepared set of instruments, in the next stages of scientific work it is possible to analyse the amount of financial support and its impact on the development of SMA.

\footnotetext{
${ }^{11}$ JEREMIE 2 is a project implemented under the Regional Operational Programmes as the continuation of the JEREMIE initiative implemented in the years 2007 - 2013, which focuses on providing repayable assistance. Financial means provided to entrepreneurs in the form of: capital entries, guarantees, microloans, investment and working capital loans, investment loans, microloans for starting a company and for creating additional new jobs.
} 


\section{REFERENCES}

Burdecka, W. (2004). Instytucje otoczenia biznesu. Warszawa: PARP, Instytut Technologi i Eksploatacji, p. 5.

ESPON project 1.4.3 Study on Urban Functions, Final Report, March 2007. Retrieved from: https://www.espon.eu/ programme/projects/espon-2006/studies-and-scientific-support-projects/study-urban-functions.

Europejskie fundusze strukturalne i inwestycyjne na lata 2014-2020, (2015).Retrieved from: https://ec.europa.eu/ regional_policy/sources/docgener/guides/blue_book/blueguide_pl.pdf.

Instrumenty finansowe w polityce spójności na lata 2014-2020, (2014). Retrieved from: https://ec.europa.eu/regional_ policy/sources/docgener/informat/2014/financial_instruments_pl.pdf,

Kaczmarek, T. (2019). Obszary metropolitalne, przesłanki i formy integracji zarządzania. Przeglqd Planisty, nr 3, 4-6.

Koncepcja Przestrzennego Zagospodarowania Kraju 2030. Uchwała Nr 239 Rady Ministrów z dnia 13 grudnia 2011 r. w sprawie przyjęcia Koncepcji Przestrzennego Zagospodarowania Kraju 2030.

Lendzion, J., Sołtys, J., Toczyski, W. (2004). Znaczenie obszarów metropolitalnych i ich otoczenia oraz współczesnych procesów metropolizacyjnych w kształtowaniu polityki regionalnej Państwa. Ekspertyza przygotowana na zamówienie Departamentu Polityki Regionalnej Ministerstwa Gospodarki i Pracy, p. 4, 5, 36.

Matusiak, K.B. (2011). Innowacje i transfer technologii Słownik pojęć. Polska Agencja Rozwoju Przedsiębiorczości, p. 126-128.

Ociepa-Kicińska, E. (2019). Instytucje otoczenia biznesu w Szczecińskim Obszarze Metropolitalnym. In Brzozowska, K. (ed.), Społeczno-gospodarcze otoczenie rozwoju lokalnego i regionalnego, pp. 117-130.

OECD Regions and Cities at a Glance 2018 (2018). OECD Publishing, Paris, p. 13. Retrieved from: https://doi.org/10.1787/ reg_cit_glance-2018-en.

Pietrowski, W. (2018). Finansowe instrumenty polityki regionalnej w Polsce. Toruń: Wydawnictwo Adam Marszałek, p. 66.

Płoszaj, A. (2013). Sieci instytucji otoczenia biznesu. Warszawa: Wydawnictwo Naukowe Scholar, p. 11.

Serwis RPO WZ, Instrumenty finansowe. Retrieved from: http://www.rpo.wzp.pl/instrumenty-finasowe).

Smętkowski, M., Jałowiecki, B., Gorzelak, G., (2009). Obszary metropolitalne w Polsce - diagnoza i rekomendacje. Studia Regionalne i Lokalne, Nr1(35)/2009. Retrieved from: http://studreg.uw.edu.pl/pdf/2009_1_smetkowski_jalowiecki_ gorzelak.pdf.

SOM. Strategia rozwoju 2020, p. 3,4,6,7. Retrieved from: http://obserwatorium.miasta.pl/wp-content/uploads/2016/08/ SzOM-2020.pdf.

Śleszyński, P., Komornicki, T. (2008). Metropolie a konkurencyjność regionów. Warszawa, Samorząd Województwa Mazowieckiego. Retrieved from: https://www.igipz.pan.pl/tl_files/igipz/ZGMiL/osoby/sleszynski/011_Sleszynski_ METROPOLIE.pdf.

UMP, Retrieved from: https://www.metropolie.pl/wp-content/uploads/2012/07/deklaracja.pdf.

Ustawa z dnia 9 października 2015 r. o związkach metropolitalnych Dz. U. z 2015 r. poz. 1890, z 2016 r. poz. 2260. 